\title{
Morphological variability of indigenous cherry plum (Prunus divaricata Ledeb.) accessions
}

\author{
P. Heidari ${ }^{1}$, M. Sahebi ${ }^{2}$, E. Azadvari ${ }^{2}$, S. Lawson ${ }^{3}$, M. Rezaei ${ }^{2}$ and A. Khadivi ${ }^{4}$ \\ ${ }^{1}$ Department of Agronomy and Plant Breeding, Faculty of Agriculture, Shahrood University of Technology, Shahrood, Iran \\ ${ }^{2}$ Department of Horticultural Sciences, Faculty of Agriculture, Shahrood University of Technology, Shahrood, Iran \\ ${ }^{3}$ USDA Forest Service, Northern Research Station, Hardwood Tree Improvement and Regeneration Center, Department of \\ Forestry and Natural Resources, Purdue University, West Lafayette, IN, U.S.A. \\ ${ }^{4}$ Department of Horticultural Sciences, Faculty of Agriculture and Natural Resources, Arak University, Arak, Iran
}

\begin{abstract}
Summary
Cherry plum (Prunus divaricata Ledeb.) is a promising species as a new rootstock for the Prunus genus. In the current study, phenotypic diversity among 43 accessions of this wild species from Hyrcanian forests in Golestan province from Iran was investigated. The selected accessions revealed significant differences in all the measured characteristics. Fruit length ranged from 10.90 to $16.40 \mathrm{~mm}$ with an average of 14.30. Ten-fruit weight varied from 5.53 to $33.50 \mathrm{~g}$ with an average of 17.70. Leaf length ranged from 19.10 to $44.60 \mathrm{~mm}$ with an average of 31.50 . Leaf width varied from 8.43 to $26.80 \mathrm{~mm}$ with an average of 17.30. Fruit weight was positively correlated with fruit length, fruit width, fruit pulp thickness, fruit stalk length, stone length, stone width, stone weight, leaf length, leaf width, and leaf symmetry. Principal component analysis (PCA) indicated seven principal components that explained $69.93 \%$ of total variance. The dendrogram clustered accessions into two main groups based on the measured traits and verified the existence of differing degrees of morphological variation among the accessions. The current study revealed a rich new genetic source for plum breeding that should be conserved in situ and ex situ.
\end{abstract}

Keywords

Iran, Prunus divaricata, breeding, morphological variation, genetic resource

\section{Introduction}

There are 20-40 plum species in the Rosaceae family, many of them intergrade from one another in the wild (Janick and Moore, 1996). European plum (Prunus domestica L.) and Japanese species such as $P$. salicina $L$. are primarily grown commercially (Okie and Hancock, 2008). Cherry plum (P. divaricata Ledeb.), a wild plum species, is diploid, self-incompatible, and widely distributed from the Balkan Peninsula across Anatolia and the Caucasus to Central Asia, including the Hyrcanian forests from northern parts of Iran (Browicz et al., 1969). Cherry plum is synonymous with 'Myrobalan' plum (P. cerasifera Ehrh. subsp. macrocarpa) (Browicz et al., 1969; Khatamsaz, 1992; Khoshbakht, 2006).

The $P$. divaricata and $P$. cerasifera have both previously been used in research on Caspian coast wild cherry plums (Khoshbakht, 2006; Wöhrmann et al., 2011; Paunoviu et

\section{Significance of this study}

What is already known on this subject?

- European plum (Prunus domestica L.) has a narrow base of genetic diversity which limits its adaptability to climate and increases its susceptibility to disease and insect attack. It may be possible to broaden the worldwide plum genetic base using diverse plum genetic resources. Cherry plum (Prunus divaricata Ledeb.) is a promising species as a new rootstock for the Prunus genus and also useful for breeding programs.

What are the new findings?

- The current study revealed a rich new genetic source for plum breeding that should be conserved in situ and ex situ.

What is the expected impact on horticulture?

- The accessions studied had valuable fruit-related traits that could be of interest in the food industry, marketing, and breeding programs.

al., 2011). The P. divaricata is a deciduous thorn-less tree or shrub with edible fruits. These fruits are often used in Western European foods after being collected from the forest (Woldring, 1997). Myrobalan plum was used as a conventional rootstock in plum orchards (Westwood, 1988) and several clones such as p.2175 and p.2980 were selected based on increased resistance to root-knot nematodes of the genus Meloidogyne (Dirlewanger et al., 2004; Lecouls et al., 2004).

The $P$. domestica has a narrow base of genetic diversity which limits its adaptability to climate and increases its susceptibility to disease and insect attack (Okie and Hancock, 2008). It may be possible to broaden the worldwide plum genetic base using diverse plum genetic resources such as Myrobalan plum, a European plum ancestor (Okie and Hancock, 2008). Cherry plums vary in color and palatability and have been used throughout Europe for selection but rarely in modern breeding. However, two cultivars were selected from chance hybrids with Myrobalan plum, 'Methley' in South Africa for its ability to self-pollinate and resistance to cold temperatures, and 'Wilson' in Australia for its miniature stature and tendency to be precocious (Okie and Hancock, 2008). Myrobalan plums have minimal fruit sizes and are likely self-fertile, cold-hardy and exhibit early maturation (Okie and Hancock, 2008). 
The Hyrcanian forest is located in the mountains of northern parts of Iran near the Caspian Sea shoreline and is one of the oldest forests in the world with highly diverse populations of tree species such as Berberis, Crataegus, Malus, Mespilus, Prunus, and Pyrus (Khoshbakht, 2006; Akhani et al., 2010; Rezaei et al., 2018; Heidari et al., 2019; Khadivi et al., 2019a, b, 2020; Mirheidari et al., 2020). This ecological region includes the coast along the Caspian Sea and the northern slopes of the Alborz Mountains in Iran which are rich in biological diversity (Akhani et al., 2010; Sagheb-Talebi et al., 2014).

Morphological traits can be used to detect genetic variation among and within plant species (Nikolic et al., 2007; Khadivi-Khub and Anjam, 2014; Rakonjac et al., 2014; Khadivi-Khub and Ebrahimi, 2015). Some phenotypic variables can be influenced by environmental factors (Tucic et al., 2018). High variation in phenological and fruit traits has been observed in plum cultivars from different parts of the world (Nikolic et al., 2007; Horvath et al., 2011; KhadiviKhub and Barazandeh, 2015; Khadivi et al., 2020). Leaf, flower, and fruit-related characteristics have been used as the primary morphological traits for characterization of inter-specific plum tree hybrids (Ertekin et al., 2006; Milosevic and Milosevic, 2012). Leaf and fruit-related traits were substantially diverse in wild plum accessions (Kaufmane et al., 2002; Aazami and Jalili, 2011).

Accessibility to plant resources and genetic information is becoming progressively more vital to the future preservation and sustainable use of genetic germplasm (Byrne et al., 2018). Deforestation in the northeastern parts of Iran has endangered the majority of plant materials in the area (Karimi et al., 2016). The genetic diversity of cherry plum has rarely been studied in this area (Khadivi et al., 2020) in comparison with other Prunus species. Investigation on morphological characteristics of wild cherry plum genotypes found in the Hyrcanian forest can help identify genetic resources for conservation or breeding programs. Thus, in the current study, morphological and pomological diversity among the native accessions of $P$. divaricata from Hyrcanian forests in Golestan province from the northeastern parts of Iran was investigated.

\section{Material and methods}

\section{Plant material}

In the current study, 43 wild accessions of cherry plum ( $P$. divaricata) were selected from several locations within two natural habitats of Golestan province from the northeastern parts of Iran, including 22 accessions from Abr area $\left(36^{\circ} 55^{\prime}-36^{\circ} 34^{\prime} \mathrm{N}, 5^{\circ} 57^{\prime}-55^{\circ} 12^{\prime} \mathrm{E}\right.$, and altitude of $800-2,650 \mathrm{~m}$ ) and 21 accessions from Olang area $\left(36^{\circ} 33^{\prime}-\right.$ $36^{\circ} 40^{\prime} \mathrm{N}, 55^{\circ} 18^{\prime}-55^{\circ} 25^{\prime} \mathrm{E}$, and altitude of $2,000-3,000 \mathrm{~m}$ )
(Figure 1). In Abr area, the average annual temperature is $20^{\circ} \mathrm{C}$ with $550 \mathrm{~mm}$ precipitation per year, while in Olang area, the average annual temperature is $12^{\circ} \mathrm{C}$ with $550 \mathrm{~mm}$ precipitation per year. The soil type of both areas is loamy. To avoid the likelihood of sampling accession clones, distances of $\sim 100 \mathrm{~m}$ were considered between the accessions.

\section{Trait measurement}

The selected accessions were evaluated based upon morphological and pomological traits described in the plum descriptor (International Union for the Protection of New Varieties of Plants, UPOV, 2002). Leaves and fruits of each accession were collected randomly from various parts of trees at full maturity. Thirty-three morphological characters were recorded for 20 mature fruits and 20 mature leaves per accession. Dimensions of leaf, fruit, and stone were measured using a digital caliper (Maxwell, China). Fruit weight and stone weight were measured using a precision-electronic balance (Sartorius, Germany). Qualitative traits such as fruit acidity, fruit color, fruit symmetry, fruit shape, fruit texture color, fruit texture stiffness, stone shape, leaf color, leaf pubescence density, leaf margin incisions, and leaf angles were estimated based on rating and coding.

\section{Data analysis}

One-way analysis of variance (ANOVA) was conducted to detect significant differences between morphological characteristics among the studied accessions with SAS ${ }^{\circledR}$ 9.4 (SAS Institute, 2015). Raw data were analyzed for mean, standard deviation (SD), and coefficients of variation (CV) with SPSS ${ }^{\circledR}$ software v. 16 (SPSS, 2007). The correlation values between traits were calculated using the Pearson correlation coefficient with SPSS ${ }^{\circledR}$ software v. 16 (SPSS, 2007). Relationships among the accessions were investigated using principal component analysis (PCA) with SPSS ${ }^{\circledR}$ software. The scatter plot of the first two principal components (PC1 and PC2) was drawn with PAST software (Hammer et al., 2001). Ward's minimum variance method was used to generate Euclidean distances for cluster analysis (CA) using PAST software (Hammer et al., 2001). Mean normalization using Z-scores was implemented prior to cluster analysis to eliminate scaling differences.

\section{Results and discussion}

\section{Morphological characteristics}

The ANOVA showed significant differences among the accessions for all the traits $(P \leq 0.05)$. Most of the traits were highly variable based on $\mathrm{CV}$ values (Table 1 ). The highest CV was recorded for fruit texture color $(80.30 \%)$ and fol-
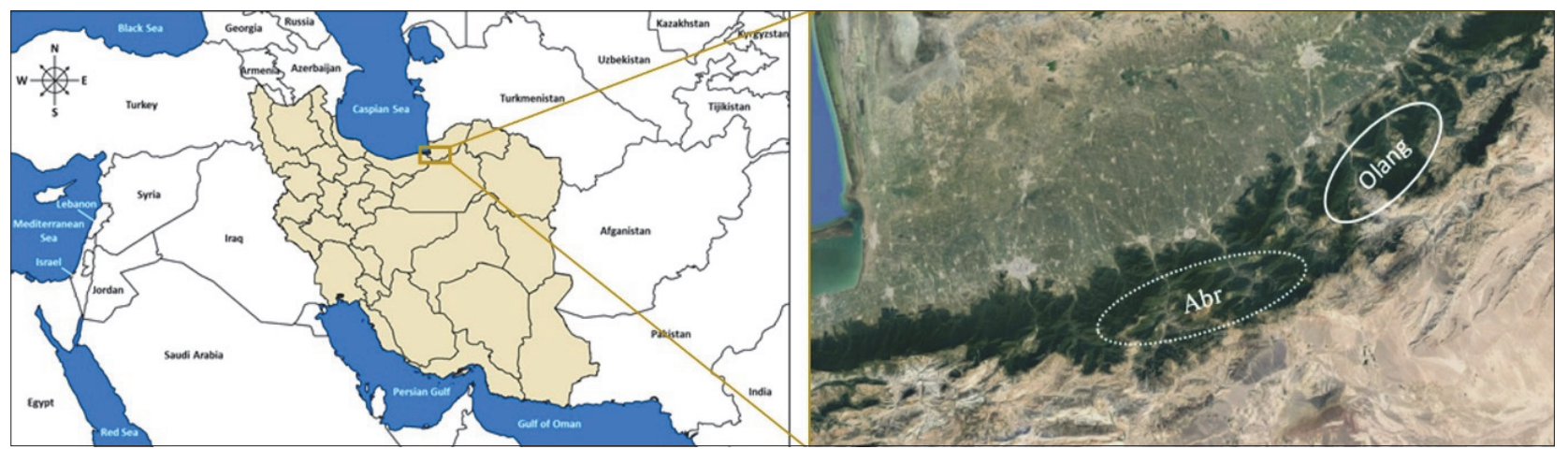

FIGURE 1. Distribution of the wild cherry plum accessions studied within Hyrcanian forest in Abr and Olang sites. 
lowed by fruit texture stiffness (74.50\%) and fruit symmetry $(70.70 \%)$. In contrast, fruit acidity and stone adherence to flesh had none variations among the accessions (CV = 0.00\%) and thus were stable. Khadivi et al. (2020) reported none variation for fruit flesh adhesion to stone in P. divaricata. In the present study, stone width $(\mathrm{CV}=9.99 \%)$, stone length ( $C V=10.20 \%)$, and fruit length ( $C V=10.90 \%)$ showed the lowest variations and corresponded with the findings of Khadivi et al. (2020). Colic et al. (2003) reported low variations for fruit and stone dimensions in cherry plum. Higher CV values denote increased variation and render those traits optimal for use in selections (Mohammadi and Prasanna, 2003). Khadivi-Khub and Barazandeh (2015) studied cultivated plums belonging to $P$. domestica and showed high diversity. Twenty-five characters showed CV values $>20.00 \%$, revealing abundant variation among the studied accessions. The CV values do not require units and are more effective in comparing measured characteristics (Khadivi-Khub and Etemadi-Khah, 2015).

Fruit size is an important trait in marketability and customer opinion. Abr-12 accession displayed the largest fruit size ( $16.40 \mathrm{~mm}$ for fruit length and $16.70 \mathrm{~mm}$ for fruit width), while Abr-13 exhibited the smallest fruit size $(10.90 \mathrm{~mm}$ for fruit length and $9.09 \mathrm{~mm}$ for fruit width). Khadivi et al. (2020) reported the range of $11.48-28.40 \mathrm{~mm}$ for fruit length and $10.33-29.23 \mathrm{~mm}$ for fruit width in P. divaricata. Ten-fruit weight ranged from 5.53 to $33.50 \mathrm{~g}$ with an average of 17.70 . Khadivi et al. (2020) reported the range of 1.79-14.09 g with an average of 4.46 for a single fruit weight in P. divaricata.

The fruits of all the accessions were extremely sour and acidic with flesh adhering tightly to the stones. Red or dark red fruits were observed in $75 \%$ of the accessions, while $11 \%$ showed black fruits, and also $14 \%$ were orange. In the Asian plums, dark skin color and fruit firmness are key factors for consumer acceptance (Okie and Hancock, 2008). The purple fruit color in P. cerasifera var. pissardii (Carriere) L.H. Bailey is controlled by a single pair of genes with heterozygous individuals having intermediate color intensity (Crane and Lawrence, 1956). Skin color is largely quantitatively inherited in $P$. domestica, although yellow skin is regulated by a single recessive gene (Okie and Hancock, 2008).

Fruit pulp thickness ranged from 1.38 (Olang-4 accession) to $7.47 \mathrm{~mm}$ (Abr-21 accession). Fruit stalk length ranged from 6.18 to $18.70 \mathrm{~mm}$ (Table 1 ). Fruits from the eval-

TABLE 1. Descriptive statistics for morphological and pomological characters in the wild cherry plum accessions studied.

\begin{tabular}{|c|c|c|c|c|c|c|c|}
\hline No. & Characteristic & Unit & Min. & Max. & Mean & SD & CV (\%) \\
\hline 1 & Ten-fruit weight & g & 5.53 & 33.50 & 17.70 & 6.00 & 33.70 \\
\hline 2 & Fruit length & $\mathrm{mm}$ & 10.90 & 16.40 & 14.30 & 1.60 & 10.90 \\
\hline 3 & Fruit width & $\mathrm{mm}$ & 9.09 & 16.70 & 13.20 & 1.80 & 13.40 \\
\hline 4 & Fruit acidity & Code & 1 & 1 & 1 & 0.00 & 0.00 \\
\hline 5 & Fruit color & Code & 1 & 7 & 3.74 & 1.80 & 46.80 \\
\hline 6 & Fruit pulp thickness & $\mathrm{mm}$ & 1.38 & 7.47 & 4.71 & 1.20 & 26.10 \\
\hline 7 & Fruit stalk length & $\mathrm{mm}$ & 6.18 & 18.70 & 12.10 & 2.80 & 23.50 \\
\hline 8 & Fruit symmetry & Code & 1 & 5 & 1.88 & 1.30 & 70.70 \\
\hline 9 & Fruit shape & Code & 1 & 3 & 2.35 & 1.00 & 40.40 \\
\hline 10 & Fruit texture color & Code & 1 & 7 & 3.14 & 2.50 & 80.30 \\
\hline 11 & Fruit texture stiffness & Code & 1 & 5 & 1.61 & 1.20 & 74.50 \\
\hline 12 & Ten-stone weight & g & 1.82 & 5.05 & 3.34 & 1.00 & 28.40 \\
\hline 13 & Stone adherence to flesh & Code & 1 & 1 & 1.00 & 0.00 & 0.00 \\
\hline 14 & Stone length & $\mathrm{mm}$ & 8.44 & 12.20 & 10.50 & 1.10 & 10.20 \\
\hline 15 & Stone width & $\mathrm{mm}$ & 6.88 & 9.93 & 8.51 & 0.90 & 9.99 \\
\hline 16 & Stone shape & Code & 1 & 3 & 2.91 & 0.40 & 14.40 \\
\hline 17 & Stone keel development & Code & 1 & 3 & 1.14 & 0.50 & 44.70 \\
\hline 18 & Stone apex shape & Code & 1 & 3 & 2.21 & 1.00 & 44.80 \\
\hline 19 & Stone shape (ventral view) & Code & 1 & 3 & 1.60 & 0.90 & 58.10 \\
\hline 20 & Stone shape (lateral view) & Code & 1 & 3 & 2.35 & 1.00 & 40.40 \\
\hline 21 & Stone width of stalk-end & Code & 1 & 5 & 2.07 & 1.10 & 51.10 \\
\hline 22 & Leaf length & $\mathrm{mm}$ & 19.10 & 44.60 & 31.50 & 6.80 & 21.50 \\
\hline 23 & Leaf width & $\mathrm{mm}$ & 8.43 & 26.80 & 17.30 & 4.30 & 25.00 \\
\hline 24 & Leaf length/leaf width & Ratio & 1.18 & 2.47 & 1.87 & 0.30 & 15.50 \\
\hline 25 & Leaf side color (adaxial) & Code & 1 & 5 & 6.05 & 1.60 & 26.50 \\
\hline 26 & Leaf side color (abaxial) & Code & 1 & 5 & 1.93 & 1.20 & 61.10 \\
\hline 27 & Leaf pubescence density (abaxial) & Code & 1 & 5 & 1.84 & 1.10 & 59.20 \\
\hline 28 & Leaf shape & Code & 1 & 5 & 3.47 & 1.60 & 45.00 \\
\hline 29 & Leaf symmetry & Code & 1 & 3 & 1.37 & 0.80 & 57.70 \\
\hline 30 & Leaf margin incisions & Code & 1 & 3 & 2.67 & 0.80 & 28.10 \\
\hline 31 & Leaf apex angle & Code & 1 & 5 & 2.63 & 1.20 & 44.90 \\
\hline 32 & Leaf base angle & Code & 1 & 5 & 2.81 & 1.40 & 51.20 \\
\hline 33 & Petiole length & $\mathrm{mm}$ & 3.29 & 10.70 & 6.72 & 1.60 & 23.20 \\
\hline
\end{tabular}


uated selections were largely symmetric with an elliptical shape, yellow pulp color, and soft texture (Table 2). In plums, round fruit shapes are dominant to oblong but less dominant than oval (Okie and Hancock, 2008).

Stone length ranged from 8.44 to $12.20 \mathrm{~mm}$, while stone width varied from 6.88 to $9.93 \mathrm{~mm}$. Ten-stone weight ranged from 1.82 to $5.05 \mathrm{~g}$ (Table 1). Only 7\% of accessions exhibited stone keel development. Most of the accessions (61\%) showed stones with a rounded apex, while $70 \%$ of the accessions displayed stones with medium elliptic shapes in vertical and $68 \%$ in lateral views. The stone width of stalk end was broad in only $2 \%$ of accessions, while it was medium in $49 \%$ and also narrow in $49 \%$ of the accessions (Table 2).

Adaxial leaf color was light green (31\%), green (37\%), and dark green $(32 \%)$, while abaxial leaf color was light green (58\%), green (37\%), and dark green (5\%). Leaf length ranged from 19.10 to $44.60 \mathrm{~mm}$ and leaf width varied from 8.43 to $26.80 \mathrm{~mm}$. The leaf length/leaf width varied from 1.18 to 2.47. Petiole length ranged from 3.29 to $10.70 \mathrm{~mm}$ (Table 1). Leaf pubescence density (abaxial) was sparse (60\%), medium (38\%), and dense (2\%). Leaf shape in the majority of accessions was symmetric obovate. Leaf margin

TABLE 2. Frequency distribution for the measured qualitative characters in the wild cherry plum accessions studied.

\begin{tabular}{|c|c|c|c|c|}
\hline \multirow{2}{*}{ Characteristic } & \multicolumn{4}{|c|}{ Code and frequency $(\%)$} \\
\hline & 1 & 3 & 5 & 7 \\
\hline Fruit acidity & High (100) & - & - & - \\
\hline Fruit color & Orange (14) & $\operatorname{Red}(47)$ & Dark red (28) & Black (11) \\
\hline Fruit symmetry & Symmetric (65) & Moderate asymmetric (26) & Asymmetric (9) & - \\
\hline Fruit shape & Round (33) & Elliptical (67) & - & - \\
\hline Fruit texture color & Yellow (33) & Yellow orange (7) & Light red (19) & $\operatorname{Red}(21)$ \\
\hline Fruit texture stiffness & Soft (77) & Medium (16) & Stiff (7) & - \\
\hline Stone adherence to flesh & Adherent (100) & - & - & - \\
\hline Stone shape & Round (5) & Elliptical (95) & - & - \\
\hline Stone keel development & Non keel (93) & Keel (7) & - & - \\
\hline Stone apex shape & Obtuse (39) & Rounded (61) & - & - \\
\hline Stone shape (ventral view) & Medium elliptic (70) & Broad elliptic (30) & - & - \\
\hline Stone shape (lateral view) & Narrow elliptic (32) & Medium elliptic (68) & - & - \\
\hline Stone width of stalk-end & Narrow (49) & Medium (49) & Broad (2) & - \\
\hline Leaf side color (adaxial) & Light green (31) & Green (37) & Dark green (32) & - \\
\hline Leaf side color (abaxial) & Light green (58) & Green (37) & Dark green (5) & - \\
\hline Leaf pubescence density (abaxial) & Sparse (60) & Medium (38) & Dense (2) & - \\
\hline Leaf shape & Ovate (21) & Elliptic (35) & Obovate (44) & - \\
\hline Leaf symmetry & Symmetric (81) & Asymmetric (19) & - & - \\
\hline Leaf margin incisions & Crenate (16) & Serrate (84) & - & - \\
\hline Leaf apex angle & Acute (28) & Right angled (63) & Obtuse (9) & - \\
\hline Leaf base angle & Acute (30) & Right angled (49) & Obtuse (21) & - \\
\hline
\end{tabular}
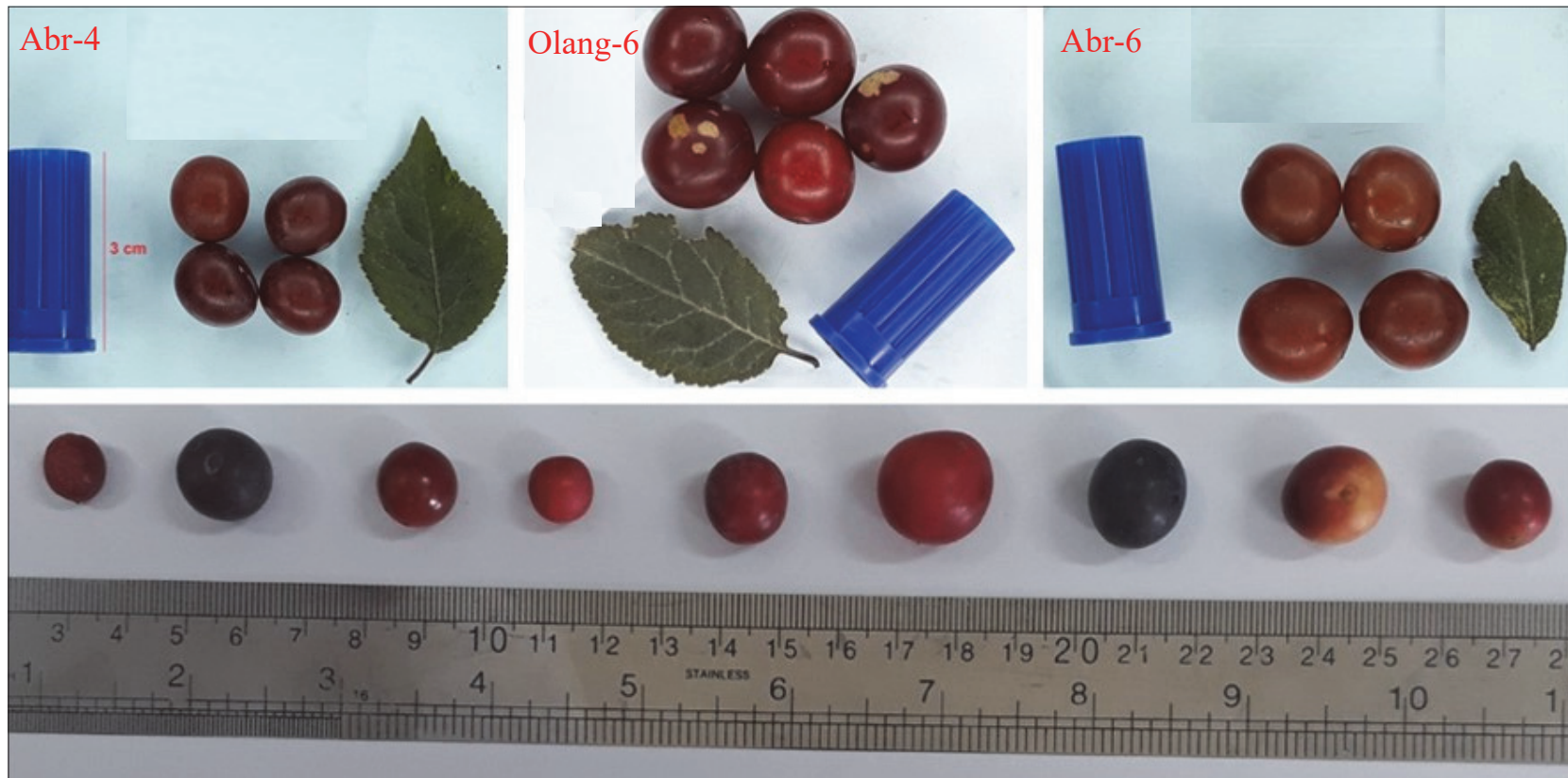

FIGURE 2. Fruits and leaves of the wild cherry plum accessions studied. 
incisions were serrate in $84 \%$ of accessions and crenate in the remaining selections (Table 2). Cherry plums with crenate leaf margins had larger fruit and stones. The variability of leaves and fruits of the studied cherry plum accessions are presented in Figure 2.

\section{Correlations among the measured characters}

Pearson correlation coefficients revealed numerous significantly positive correlations between the measured characters and several negative correlations (data not shown). Fruit weight was positively correlated with fruit length $(r=0.81)$, fruit width $(r=0.73)$, fruit pulp thickness $(r=0.62)$, fruit stalk length $(r=0.34)$, stone length $(r=0.70)$, stone width $(r=0.62)$, stone weight $(r=0.62)$, leaf length $(r=0.34)$, leaf width $(r=0.34)$, and leaf symmetry $(r=0.37)$ supporting the previous results in plum (Milosevic and Milosevic, 2012; Khadivi-Khub and Barazandeh, 2015; Khadivi et al., 2020; Mirheidari et al., 2020). Fruit length was positively correlated with fruit width $(r=0.79)$, fruit pulp thickness $(r=0.69)$, stone length $(r=0.85)$, stone width $(r=0.66)$, and stone weight $(r=0.65)$ in accordance with the previous results in plum (Milosevic and Milosevic, 2012; Khadivi-Khub and Barazandeh, 2015; Khadivi et al., 2020; Mirheidari et al., 2020). Stone length was positively correlated with stone width $(r=0.77)$, stone weight $(r=0.76)$, leaf length $(r=0.36)$, leaf width $(r=0.33)$, and petiole length $(r=0.32)$ and agreed with the previous results in plum (Milosevic and Milosevic, 2012; Khadivi-Khub and Barazandeh, 2015; Khadivi et al., 2020; Mirheidari et al., 2020).

\section{PCA and CA}

The PCA uses the observed characteristics that may be related and orthogonally converts to a numerical value. Characteristics are reduced to discriminate accessions and relationships established using PCA may inform genetic linkages between loci controlling the observed traits or indi-

TABLE 3. Eigenvectors and eigenvalues for PCA of morphological and pomological traits of the wild cherry plum accessions studied.

\begin{tabular}{|c|c|c|c|c|c|c|c|}
\hline \multirow{2}{*}{ Characteristic } & \multicolumn{7}{|c|}{ Component } \\
\hline & 1 & 2 & 3 & 4 & 5 & 6 & 7 \\
\hline Ten-fruit weight & $0.82^{* *}$ & 0.00 & -0.19 & 0.32 & -0.07 & 0.05 & 0.09 \\
\hline Fruit length & $0.86^{* *}$ & 0.11 & -0.34 & 0.18 & -0.09 & 0.06 & -0.06 \\
\hline Fruit width & $0.87^{* *}$ & -0.13 & 0.03 & 0.33 & 0.10 & 0.03 & -0.16 \\
\hline Fruit color & -0.21 & 0.38 & -0.26 & $0.56^{\star \star}$ & 0.14 & -0.02 & 0.08 \\
\hline Fruit pulp thickness & $0.64^{* *}$ & -0.10 & -0.07 & 0.42 & 0.16 & 0.08 & -0.21 \\
\hline Fruit stalk length & $0.53^{* *}$ & -0.11 & 0.36 & -0.12 & 0.02 & -0.39 & -0.05 \\
\hline Fruit symmetry & 0.42 & $-0.54^{* *}$ & 0.12 & -0.06 & -0.40 & 0.24 & -0.02 \\
\hline Fruit shape & -0.03 & 0.12 & $-0.57^{* *}$ & -0.44 & -0.37 & 0.10 & 0.05 \\
\hline Fruit texture color & -0.22 & 0.22 & -0.08 & $0.62^{* *}$ & 0.17 & -0.35 & 0.05 \\
\hline Fruit texture stiffness & 0.20 & -0.16 & 0.10 & -0.24 & -0.14 & -0.40 & $-0.51^{* *}$ \\
\hline Stone length & $0.86^{* *}$ & 0.04 & -0.27 & -0.15 & -0.20 & -0.09 & 0.07 \\
\hline Stone width & $0.88^{* *}$ & -0.12 & 0.16 & -0.05 & -0.03 & -0.07 & -0.03 \\
\hline Stone shape & 0.18 & 0.48 & -0.19 & -0.12 & -0.34 & 0.22 & 0.08 \\
\hline Ten-stone weight & $0.89^{* *}$ & -0.15 & 0.21 & -0.06 & -0.05 & -0.05 & 0.01 \\
\hline Stone keel development & 0.11 & -0.49 & 0.32 & 0.18 & -0.09 & -0.02 & 0.49 \\
\hline Stone apex shape & 0.26 & 0.01 & $0.54^{* *}$ & -0.37 & -0.03 & 0.14 & -0.30 \\
\hline Stone shape (ventral view) & 0.05 & $-0.52^{* *}$ & 0.50 & 0.26 & 0.13 & -0.05 & -0.03 \\
\hline Stone shape (lateral view) & -0.11 & -0.22 & 0.71 & 0.02 & 0.23 & 0.04 & -0.05 \\
\hline Stone width of stalk-end & -0.26 & -0.04 & 0.21 & 0.41 & -0.09 & 0.21 & 0.17 \\
\hline Leaf length & 0.48 & 0.30 & -0.06 & -0.40 & $0.57^{* *}$ & 0.17 & 0.02 \\
\hline Leaf width & 0.49 & $0.71^{\star *}$ & 0.15 & -0.14 & 0.31 & 0.03 & -0.01 \\
\hline Leaf length/leaf width & -0.20 & $-0.74^{* *}$ & -0.26 & -0.26 & 0.25 & 0.16 & 0.08 \\
\hline Petiole length & 0.30 & -0.07 & -0.35 & $-0.56^{* *}$ & 0.40 & -0.02 & 0.27 \\
\hline Leaf side color (abaxial) & 0.06 & 0.39 & $0.53^{* *}$ & 0.01 & -0.08 & 0.07 & 0.27 \\
\hline Leaf side color (adaxial) & -0.13 & 0.09 & 0.50 & -0.34 & -0.28 & -0.08 & 0.43 \\
\hline Leaf pubescence density (abaxial) & 0.10 & 0.23 & 0.16 & -0.06 & $0.63^{* *}$ & 0.32 & 0.14 \\
\hline Leaf shape & -0.05 & 0.47 & $0.55^{\star *}$ & -0.10 & -0.29 & 0.23 & -0.17 \\
\hline Leaf symmetry & 0.25 & 0.05 & -0.15 & 0.27 & -0.28 & $0.66^{\star *}$ & 0.05 \\
\hline Leaf margin incisions & -0.50 & 0.21 & -0.17 & -0.04 & -0.03 & -0.05 & $-0.54^{* *}$ \\
\hline Leaf apex angle & 0.24 & 0.24 & -0.22 & 0.00 & -0.15 & -0.61 & 0.39 \\
\hline Leaf base angle & 0.14 & 0.72 & 0.41 & 0.07 & -0.12 & -0.12 & 0.01 \\
\hline Total & 6.70 & 3.61 & 3.43 & 2.69 & 1.99 & 1.69 & 1.57 \\
\hline$\%$ of Variance & 21.61 & 11.66 & 11.06 & 8.67 & 6.41 & 5.46 & 5.06 \\
\hline Cumulative \% & 21.61 & 33.27 & 44.33 & 53.00 & 59.41 & 64.87 & 69.93 \\
\hline
\end{tabular}

${ }^{* *}$ Eigenvalues $\geq 0.51$ are significant. 


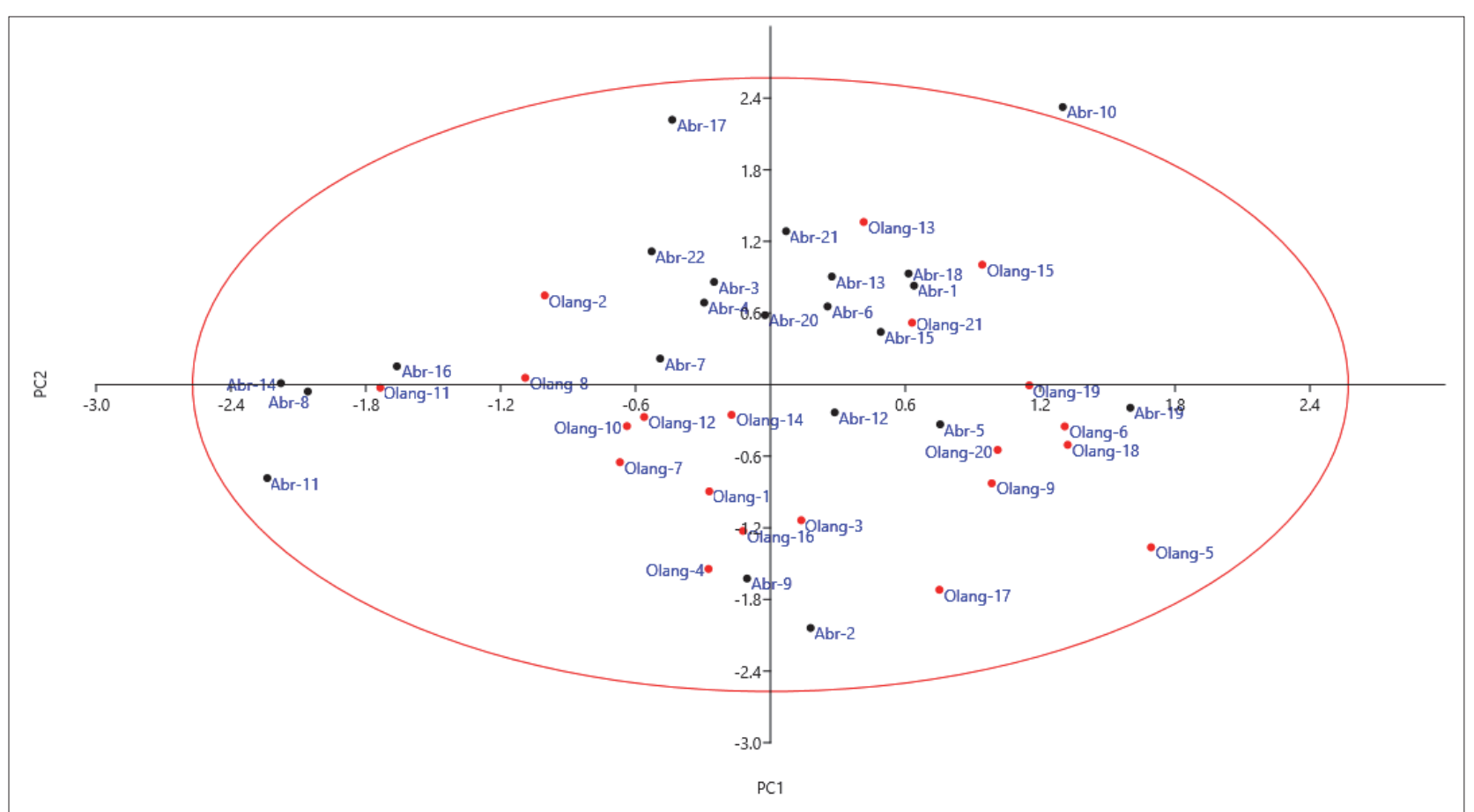

FIGURE 3. Scatter plot for PC1 and PC2 (33.27\% of total variance) of the wild cherry plum accessions studied.

cate pleiotropic effects (Iezzoni, 2008). Associations among phenotypic traits are very useful for distinguishing variance among different plum species (Kaufmane et al., 2002; Aazami and Jalili, 2011; Milosevic and Milosevic, 2012; Khadivi-Khub and Barazandeh, 2015; Khadivi et al., 2020; Mirheidari et al., 2020).

Seven PCs with eigenvalues $\geq 1$ explained $69.93 \%$ of total variance (Table 3). The first three PCs explained $44.33 \%$ of total variance. The PC1 accounted for $21.61 \%$ of the overall variance and positively correlated ten-fruit weight, fruit length, fruit width, fruit pulp thickness, fruit stalk length, stone length, stone width, and ten-stone weight. Fruit symmetry, stone shape in ventral view, leaf width, and leaf length/leaf width were correlated with PC2 and explained $11.66 \%$ of total variance. The PC3 explained $11.06 \%$ of variance detected and showed significant correlations with fruit shape, stone apex shape, leaf lower side color (abaxial), and leaf shape. The remaining PCs (PC4-PC7) accounted for $25.60 \%$ of total variance and included the remaining characteristics, indicating the minimal effect of those traits on differentiating between accessions.

A two-dimensional scatter plot was created based on PC1 and PC2 (33.27\% of total variance) for determination of relationships among the accessions (Figure 3). Neighboring accessions were more similar in terms of the effective traits in PC1 and PC2 and sorted to the same group. Phenotypic variability among the accessions was captured with the scatter plot and showed the wide-ranging distribution. Residuals formed a horizontal band along the 0.00 line. This suggests variances of the error terms are equal and accession relationships are linear. Abr-10 accession was a notable outlier among the accessions evaluated likely due to the extreme fruit size and weight observed. The loading plot indicated the importance of fruit-related traits for explaining variance among the accessions and agreed with other plum findings (Milosevic and Milosevic, 2012; Khadivi-Khub and Barazandeh, 2015; Khadivi et al., 2020; Mirheidari et al., 2020).

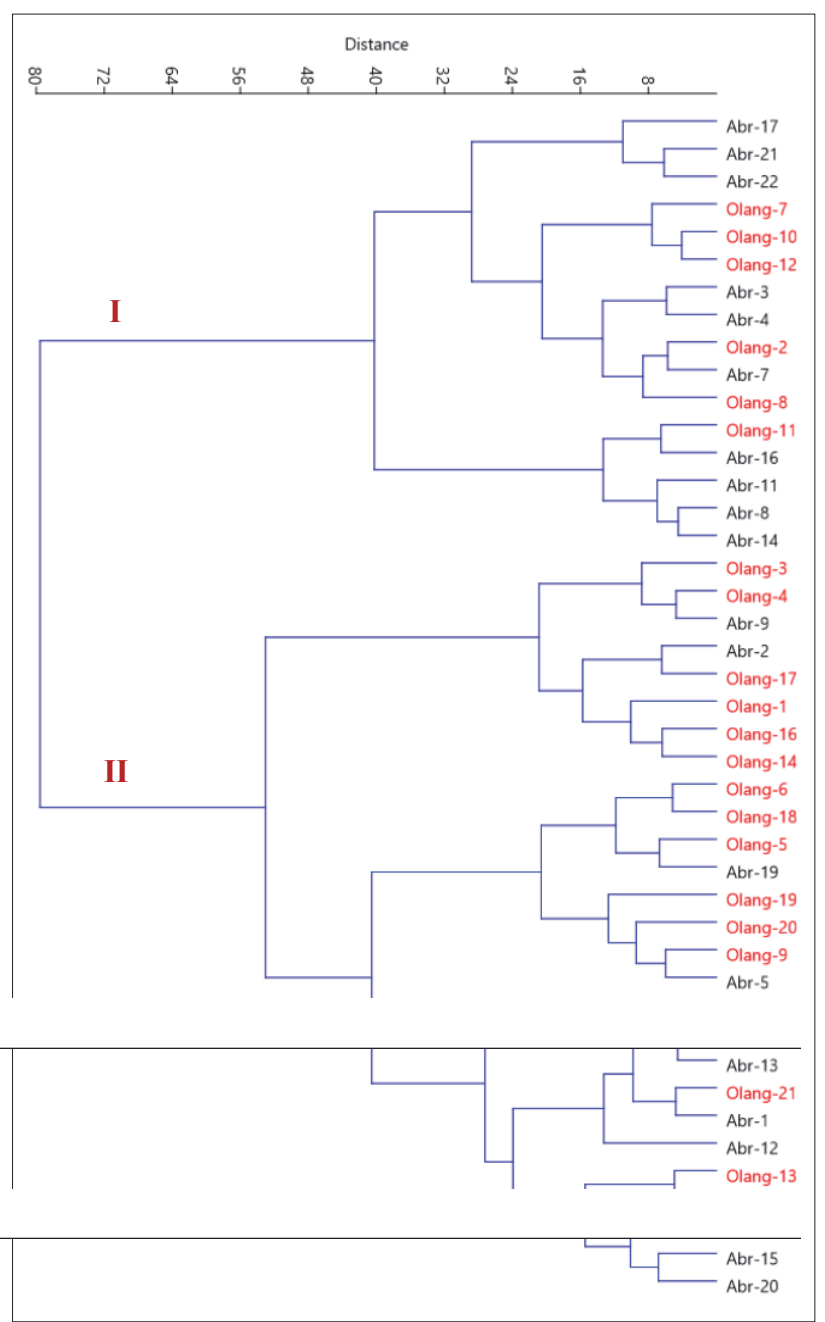

FIGURE 4. Ward cluster analysis of the wild cherry plum accessions studied using Euclidean distances based on morphological traits. 
Cluster analysis (CA) using all the measured morphological characters showed that the accessions were grouped into two main clusters (Figure 4). The first cluster (I) consisted of 16 accessions. The second cluster (II) included 27 accessions. Colic et al. (2003) and Khadivi et al. (2020) studied the phenotypic variability of the wild cherry plum and showed extensive morphological variability among the native cherry plum accessions of this area.

\section{Conclusions}

Commercial European plums ( $P$. domestica) have a narrow genetic base which can render the population more susceptible to abiotic and biotic stresses. Cherry plum, a European plum ancestor, appears to be a promising species to aid breeding programs for purposes of increasing genetic variation and use in the trait selection. Conversely, Myrobalan plum, a conventional plum rootstock for wild cherry plums in wet forests with heavy soils, can be a useful source for new rootstock breeding materials along with the evaluation of soil pathogen and flooding resistances. Recording morphological and pomological characteristics have historically been important to diversity analyses. Fruit and stone-related characteristics such as weight, size, and color were key traits to observe the variability within the collected cherry plum (P. divaricata) accessions. The results presented here indicated wild cherry plums in Hyrcanian forests have fruiting characteristics that may be essential to breeding programs or for the conservation of genetic resources. The current research revealed a rich supply of genetic material for use in breeding and in situ and ex situ conservation efforts.

\section{Conflict of interest}

The authors declare that they have no conflict of interest.

\section{References}

Aazami, M.A., and Jalil, E. (2011). Study of genetic diversity in some Iranian plum genotypes based on morphological criteria. Bulgarian Agric. Sci. 17, 424-428.

Akhani, H., Morteza, D., Ghorbanalizadeh, A., and Ramezani, E. (2010). Plant biodiversity of Hyrcanian relict forests, N. Iran: An overview of the flora, vegetation, palaeoecology and conservation. Pakistan J. Bot. 42 (Special Issue), 231-258.

Browicz, K., Frohner, S., Gilli, A., et al. (1969). Rosaceae. In Flora Iranica, K.H. Rechinger, ed. (Graz, Austria: Akademische Druck- u. Verlagsanstalt), p. 1-217.

Byrne, P.F., Volk, G.M., Gardner, C., Gore, M.A., Simon, P.W., and Smith, S. (2018). Sustaining the future of plant breeding: The critical role of the USDA-ARS National Plant Germplasm System. Crop Sci. 58(2), 1-18. https://doi.org/10.2135/cropsci2017.05.0303.

Colic, S., Gordan, Z., Dejan, M., and Janković, Z. (2003). Genetic and phenotypic variability of cherry plum (Prunus cerasifera Ehrh.) pomological characteristics. Genetika 35(3), 155-160. https://doi. org/10.2298/GENSR0303155C.

Crane, M.B., and Lawrence, W.J. (1956). Genetics of Garden Plants, $4^{\text {th }}$ edn. (New York, U.S.A.: Macmillan and Co., Ltd.).

Dirlewanger, E., Cosson, P., Howad, W., Capdeville, G., Bosselut, N., Claverie, M., Voisin, R., Poizat, C., Lafargue, B., and Baron, O. (2004). Microsatellite genetic linkage maps of myrobalan plum and an almond-peach hybrid-location of root-knot nematode resistance genes. Theor. Appl. Genet. 109(4), 827-838. https://doi. org/10.1007/s00122-004-1694-9.

Ertekin, C., Gozlekci, S., Kabas, O., Sonmez, S., and Akinci, I. (2006). Some physical, pomological and nutritional properties of two plum
(Prunus domestica L.) cultivars. J. Food Engin. 75(4), 508-514. https://doi.org/10.1016/j.jfoodeng.2005.04.034.

Hammer, Ø., Harper, D.A.T., and Ryan, P.D. (2001). PAST: Paleontological Statistics Software Package for Education and Data Analysis. Palaeontol. Electron. 4(1), 9. http://palaeoelectronica. org/2001_1/past/issue1_01.htm.

Heidari, P., Rezaei, M., Sahebi, M., and Khadivi, A. (2019). Phenotypic variability of Pyrus boissieriana Buhse: Implications for conservation and breeding. Sci. Hortic. 247, 1-8. https://doi.org/10.1016/j. scienta.2018.11.075.

Horvath, A., Balsemin, E., Barbot, J.C., Christmann, H., Manzano, G., Reynet, P., Laigret, F., and Mariette, S. (2011). Phenotypic variability and genetic structure in plum (Prunus domestica L.), cherry plum (P. cerasifera Ehrh.) and sloe (P. spinosa L.). Sci. Hortic. 129(2), 283293. https://doi.org/10.1016/j.scienta.2011.03.049.

Iezzoni, A.F. (2008). Cherries. In Temperate Fruit Crop Breeding (Springer), p. 151-176. https://doi.org/10.1007/978-1-40206907-9_5.

Janick, J., and Moore, J.N. (1996). Fruit Breeding, Tree and Tropical Fruits, Vol. 1. (John Wiley and Sons).

Karimi, N., Golian, S., and Karimi, D. (2016). Monitoring deforestation in Iran, Jangal-Abr Forest using multi-temporal satellite images and spectral mixture analysis method. Arab. J. Geosci. 9, 214. https://doi. org/10.1007/s12517-015-2250-4.

Kaufmane, E., Ikase, L., Trajkovski, V., and Lacis, G. (2002). Evaluation and characterization of plum genetic resources in Sweden and Latvia. Acta Hortic. 577, 207-213. https://doi.org/10.17660/ ActaHortic.2002.577.34.

Khadivi, A., Heidari, P., Rezaei, M., Safari-Khuzani, A., and Sahebi, M. (2019a). Morphological variabilities of Crataegus monogyna and C. pentagyna in Northeastern areas of Iran. Industrial Crops Prod. 139, 111531. https://doi.org/10.1016/j.indcrop.2019.111531.

Khadivi, A., Rezaei, M., Heidari, P., Safari-Khuzani, A., and Sahebi, M. (2019b). Morphological and fruit characterizations of common medlar (Mespilus germanica L.) germplasm. Sci. Hortic. 252, 38-47. https://doi.org/10.1016/j.scienta.2019.03.014.

Khadivi, A., Mirheidari, F., Moradi, Y., and Paryan, S. (2020). Phenotypic and fruit characterizations of Prunus divaricata Ledeb. germplasm from the north of Iran. Sci. Hortic. 261, 109033. https:// doi.org/10.1016/j.scienta.2019.109033.

Khadivi-Khub, A., and Anjam, K. (2014). Morphological characterization of Prunus scoparia using multivariate analysis. Plant Syst. Evol. 300(6), 1361-1372. https://doi.org/10.1007/ s00606-013-0967-7.

Khadivi-Khub, A., and Barazandeh, M. (2015). A morphometric study of autochthonous plum genotypes based on multivariate analysis. Erwerbs-Obstbau 57, 185-194. https://doi.org/10.1007/s10341015-0247-5.

Khadivi-Khub, A., and Ebrahimi, A. (2015). The variability in walnut (Juglans regia L.) germplasm from different regions in Iran. Acta Physiol. Plant. 37(3), 1-11. https://doi.org/10.1007/s11738-0151806-y.

Khadivi-Khub, A., and Etemadi-Khah, A. (2015). Phenotypic diversity and relationships between morphological traits in selected almond (Prunus amygdalus) germplasm. Agroforestry Syst. 89(2), 205-216. https://doi.org/10.1007/s10457-014-9754-X.

Khatamsaz, M. (1992). Rosaceae. In Flora of Iran (Research Institute of Forests and Rangelands), p. 1-352.

Khoshbakht, K. (2006). Agrobiodiversity of Plant Genetic Resources in Savadkouh, Iran, with Emphasis on Plant Uses and Socioeconomic Aspects (Kassel, BRD: Kassel University Press GmbH). 
Lecouls, A.C., Bergougnoux, V., Rubio-Cabetas, M.J., Bosselut, N., Voisin, R., Poessel, J.L., Faurobert, M., Bonnet, A., Salesses, G., and Dirlewanger, E. (2004). Marker-assisted selection for the widespectrum resistance to root-knot nematodes conferred by the $\mathrm{Ma}$ gene from Myrobalan plum (Prunus cerasifera) in interspecific Prunus material. Mol. Breed. 13(2), 113-124. https://doi. org/10.1023/B:MOLB.0000018758.56413.cf.

Milosevic, T., and Milosevic, N. (2012). Phenotypic diversity of autochthonous European (Prunus domestica L.) and Damson (Prunus insititia L.) plum accessions based on multivariate analysis. Hortic. Sci. (Prague) 39(1), 8-20. https://doi.org/10.17221/99/2011HORTSCI.

Mirheidari, F., Khadivi, A., Moradi, Y., and Paryan, S. (2020). The selection of superior plum (Prunus domestica L.) accessions based on morphological and pomological characterizations. Euphytica 216, art. 87. https://doi.org/10.1007/s10681-020-02617-7.

Mohammadi, S.A., and Prasanna, B.M. (2003). Analysis of genetic diversity in crop plants - Salient statistical tools and considerations. Crop Sci. 43(4), 1235-1248. https://doi.org/10.2135/ cropsci2003.1235.

Nikolic, D., Rakonjac, V., Milutinović, M., and Fotirić, M. (2007). Variability and heritability of morphological and chemical fruit properties in cherry plum (Prunus cerasifera Ehrh.). Voćarstvo 41(1), 45-49.

Okie, W.R., and Hancock, J.F. (2008). Plums. In Temperate Fruit Crop Breeding (Springer), p. 337-358. https://doi.org/10.1007/978-14020-6907-9_11.

Paunoviu, G., Miloseviü, T., and Glisiu, I. (2011). Morphometric traits of newly bred rootstocks suckers in domestic and cherry plum. Acta Sci. POL-Hortoru. 10(2), 203-212.

Rakonjac, V., Mratinic, E., Jovkovic, R., and Fotiric Aksic, M. (2014). Analysis of morphological variability in wild cherry (Prunus avium L.) genetic resources from Central Serbia. J. Agr. Sci. Techn. 16(1), 151-162.

Rezaei, M., Sarkhosh, A., and Balandari, A. (2018). Characterization of valuable Indigenous barberry (Berberis sp.) germplasm by using multivariate analysis. Intl. J. Fruit Sci. 20(1), 1-19. https://doi.org/ 10.1080/15538362.2018.1555508.

Sagheb-Talebi, K., Pourhashemi, M., and Sajedi, T. (2014). Forests of Iran: A Treasure from the Past, A Hope for the Future (Springer). https://doi.org/10.1007/978-94-007-7371-4.

SAS Institute (2015). Base SAS 9.4 Procedures Guide.

SPSS Inc. (2007). SPSS v. 16.0. (Chicago, IL: SPSS Inc.).

Tucic, B., Budecevic, S., Jovanovic, S.M., Vuleta, A., and Klingenberg, C.P. (2018). Phenotypic plasticity in response to environmental heterogeneity contributes to fluctuating asymmetry in plants: First empirical evidence. J. Evo. Bio. 31(2), 197-210. https://doi. org/10.1111/jeb.13207.

UPOV (2002). Guidelines for the conduct of tests for distinctness, uniformity and stability, European plum (Prunus domestica L.) TG/41/5(PROJ). https://www.upov.int/meetings/en/doc_details. jsp?meeting_id=4529\&doc_id=177458.

Westwood, M.N. (1988). Temperate-zone Pomology (Timber Press).

Wohrmann, T., Guicking, D., Khoshbakht, K., and Weising, K. (2011). Genetic variability in wild populations of Prunus divaricata Ledeb. in Northern Iran evaluated by EST-SSR and genomic SSR marker analysis. Genet. Res. Crop Evol. 58(8), 1157-1167. https://doi. org/10.1007/s10722-010-9648-3.

Woldring, H. (1997). On the origin of plums: A study of sloe, damson, cherry plum, domestic plums and their intermediate forms. Palaeohistoria 39, 535-562.
Received: Apr. 21, 2020

Accepted: Sep. 27, 2021

Addresses of authors:

Parviz Heidari ${ }^{1}$, Mohammad Sahebi ${ }^{2}$, Elham Azadvari²,

Shaneka Lawson ${ }^{3}$, Mehdi Rezaei ${ }^{2}$ and Ali Khadivi ${ }^{4, *}$

${ }^{1}$ Department of Agronomy and Plant Breeding, Faculty of Agriculture, Shahrood University of Technology, Shahrood, Iran

${ }^{2}$ Department of Horticultural Sciences, Faculty of Agriculture, Shahrood University of Technology, Shahrood, Iran

${ }^{3}$ USDA Forest Service, Northern Research Station, Hardwood Tree Improvement and Regeneration Center (HTIRC), FORS309, Department of Forestry and Natural Resources, Purdue University, 715 West State Street,

West Lafayette, IN 47907, U.S.A.

${ }^{4}$ Department of Horticultural Sciences, Faculty of Agriculture and Natural Resources, Arak University, 38156-8-8349 Arak, Iran

* Corresponding author; E-mail: a-khadivi@araku.ac.ir Tel./Fax: +98-86-32762087 